\title{
Synody w Afryce prokonsularnej III wieku jako przejaw kolegialności biskupów w świetle Kanonów synodalnych i Listów św. Cypriana z Kartaginy
}

W III wieku związki Kościołów Afrykańskiego i Rzymskiego były bardzo intensywne. Zachowała się obfita korespondencja świadcząca o wzajemnej trosce o losy tych gmin. Podobne wyzwania pojawiły się zarówno we wspólnocie, której przewodniczył św. Cyprian, biskup Kartaginy, jak i w tej, na czele której stał następca św. Piotra w Rzymie ${ }^{2}$. Sytuacja chrześcijan w połowie III wieku bardzo się skomplikowała ze względu na pojawienie się kilku grup heterodoksyjnych oraz rozłamów we wspólnotach, co najbardziej uwidoczniło się czasie prześladowania. Niniejsze opracowanie jest próbą ukazania ważnej roli synodów w kształtowaniu kolegialności biskupów w Afryce prokonsularnej w połowie III wieku w kontekście troski o jedność Kościoła. Warto bowiem zapytać, czy uchwały synodów jako przejawu kolegialności biskupów Afryki prokonsularnej wpłynęły na doktrynę Kościoła.

W Afryce prokonsularnej w końcu II wieku wspólnoty chrześcijańskie działały dość prężnie. Świadczyć może o tym twórczość pisarska Tertuliana (ok. 160-220). Właśnie on szczególnie w pierwszym okresie swojej działalności pisarskiej oddał wielkie przysługi chrześcijaństwu, to jednak już od ok. 205 roku w jego postawie uwidoczniły się silne tendencje rygorystyczne, czego przejawem była obecność w Kartaginie montanistów ${ }^{3}$, do

1 Ks. dr hab. Stanisław Strękowski, prof. UKSW, pracownik Wydziału Studiów nad Rodziną na Uniwersytecie Kardynała Stefana Wyszyńskiego w Warszawie; e-mail: stanislawstrekowski@wp.pl; ORCID: 0000-0001-9998-8554.

2 H. Koch, Cyprian und der Romische Primat, „Texte und Untersuchungen” 35 (1910) s. 158-169.

3 Por. obszerne opracowania: J. Słomka, Nowe proroctwo. Historia i doktryna montanizmu, Katowice 2007; P.Ch. de Labriolle, La crise montaniste, Paris 1913; L.D. Powell, Tertullianists and Cataphrygians, VigCh 29/1 (1975) s. 33-54. 
których przyłączył się ten wybitny apologeta i polemista, podejmując wiele zagadnień bliskich „nowemu proroctwu”, aby pod koniec swego życia utworzyć jeszcze bardziej radykalny nurt zwany od jego imienia tertulianizmem $^{4}$. Tej sekcie biskupi musieli stawiać czoła zarówno w Kartaginie, jak i w sąsiednich wspólnotach jeszcze przez długi czas aż do św. Augustyna. Należy jednak zaznaczyć, że prawdziwe spustoszenie wśród wyznawców Chrystusa nie tylko w Afryce, lecz również w innych gminach pojawiło się wraz z prześladowaniem zarządzonym przez cesarza Decjusza, a później i jego następców, które ogarnęło całe Imperium ${ }^{5}$.

Św. Cyprian Męczennik właśnie w tym przełomowym okresie, po śmierci biskupa Donata, rozpoczął swoją działalność pasterską w Kartaginie. $\mathrm{O}$ wyzwaniach duszpasterskich w tym czasie mówią nie tylko kanony synodów w Kartaginie, w których brali udział członkowie kleru afrykańskiego i biskupi innych wspólnot chrześcijańskich, lecz również w swoich Listach do poszczególnych pasterzy i wiernych o podjętych uchwałach informował wspólnotę chrześcijan w Rzymie sam św. Cyprian ${ }^{6}$. Oprócz tych dokumentów zachowały się do naszych czasów Akta Synodalne z 256 roku dotyczące chrztu heretyków.

\section{Kolegialność w pierwotnym Kościele}

Kolegialność w dokumentach z Afryki prokonsularnej połowy III wieku można zauważyć na dwóch poziomach: pomiędzy metropolitami (w przypadku Cypriana z biskupami Rzymu i biskupami Hiszpanii) oraz z biskupami i klerem własnej prowincji. Główną linią tych działań była jedność Kościoła oraz rozwiązywanie problemów dyscyplinarnych, które pojawiły się we wspólnocie chrześcijan po prześladowaniach Decjusza

4 J. Danielou - H.I. Marrou, Historia Kościoła, t. 1, tł. M. Tarnowska, Warszawa 1986, s. 143.

5 Por. P. Keresztes, Two Edicts of the Emperor Valerian, VigCh 29/2 (1975) s. 81-95; J.B. Rives, The Decree of Decius and the religion of empire, ,,Journal of Roman Studies”, 89 (1999) s. 135-154; C.C. Berardi, La persecuzione di Decio negli scritti di Cipriano, „Auctores nostri” 1 (2004) s. 41-60.

6 M. Drogosz, Cyprian, biskup Kartaginy wobec swojego kleru (w świetle jego Listów), „Śląskie Studia Historyczno-Teologiczne” 18 (1985) s. 149-152; J.H. Taylor, St. Cyprian and the reconciliation of apostates, ,Theological Studies” 3/1 (1942) s. 2746; J. Grzywaczewski, The validity of the baptism of heretics according to Cyprian of Carthage, pope Stephan and Firmilian of Caesarea, VoxP 63 (2015) s. 95-112. 
i jego następców? ${ }^{7}$ Należały do nich problem schizmatyków i heretyków, problem upadłych w czasie prześladowań $\mathrm{i}$ ich powrotu do wspólnoty Kościoła, ważność chrztu heretyków i schizmatyków oraz chrzest dzieci. Szczególną płaszczyzną w rozwiązywaniu tych problemów były kongregacje biskupów i kleru na synodach ${ }^{8}$ prowincji, którym przewodniczył św. Cyprian z Kartaginy9.

W obliczu problemu przyjęcia do Kościoła pogan Apostołowie zebrali się na tzw. pierwszym soborze lub synodzie, aby wspólnie podjąć decyzję w tej kwestii i tradycja utrzymywania kontaktów między wspólnotami i ich pasterzami stała się trwałym elementem życia chrześcijańskiego. Synody były zwoływane nie tylko w Kartaginie. Z informacji, które zachowały się w źródłach od tzw. Soboru Jerozolimskiego na Wschodzie i Zachodzie Imperium, do czasów Cypriana było zwoływanych ok. 20 synodów, na których rozpatrywano różne kwestie nurtujące liczne wspólnoty chrześcijańskie. Obradowano o dacie Wielkanocy (w Rzymie w 154-193 roku, w Azji Mniejszej w 198-199 roku, w Mezopotamii i Edessie ok. 196 roku, w Poncie i Lugdunum - 197 roku oraz w Cezarei Palestyńskiej), przeciwko doktrynom gnostyckim i adopcjonistom, montanistom (Hierapolis ok. 150170 rok), przeciwko Orygenesowi (w Aleksandrii i Rzymie w 231 roku), przeciwko Ammoniosowi (Aleksandria w 235 roku), o chrzcie udzielanym przez heretyków (Ikonium e 230-235 roku), przeciwko błędom biskupa Privatusa (w Numidii w 240 roku) i monarchianizmowi Noetosa (Azja Mniejsza w 245 roku). Nie zachowały się wszystkie dokumenty dotyczące zwoływanych synodów, o niektórych posiadamy wzmianki u Euzebiusza z Cezarei i Epifaniusza ${ }^{10}$.

Św. Ignacy, biskup Antiochii, w swojej podróży do Rzymu na początku II wieku kontaktuje się z gminami, które znalazły się na jego drodze i adresuje do nich swoje sławne Listy, w których daje szereg wskazówek dla wyznawców Chrystusa. Szczególnie znamienny jest List do Efezjan, w którym zaznacza, że wszyscy chrześcijanie są współwędrowcami, są nosicielami Boga, Chrystusa, świętych przedmiotów, we wszystkim przy-

7 Por. M. Bogucki, Problemy duszpasterskie $w$ listach św. Cypriana, ,, Studia Theologica Varsaviensia” 9/1 (1971) s. 191-224.

8 „Synod” to starożytne słowo zakorzenione w tradycji Kościoła, którego znaczenie przypomina najgłębszą treść Objawienia. Grecki termin synodos odnosi się do Jezusa, który objawia się ludziom jako „droga, prawda i życie” (J 14,6), a także do faktu, że chrześcijanie, naśladowcy swego Mistrza, byli pierwotnie „naśladowcami drogi Jezusa” (Dz 9,2; 19,9.23; 22,4; 24,14.22).

9 P. Zmire, Recherches sur la collégialité épiscopale dans l'Église d'Afrique, „Recherches Augustiniennes” 1 (1971) s. 27-28.

10 Acta Synodalia ann. 50-381, red. A. Baron - H. Pietras, Kraków 2006, s. 2*-5*. 
ozdobieni przykazaniami Jezusa Chrystusa ${ }^{11}$. Od początku bowiem biskupi wymieniali między sobą korespondencję, informując o trudnościach i wyzwaniach, udzielając sobie wzajemnie rad, interpretując różnego rodzaju rozwiązania. Świadczyć może o tym List wspomnianego św. Ignacego Antiocheńskiego do Polikarpa, a w IV wieku Listy św. Bazylego Wielkiego do biskupa Aleksandrii Atanazego, Meletiosa, biskupa Antiochii, biskupów Galii i Italii (List 243).

W III wieku Kartagina stała się ważnym centrum życia chrześcijańskiego. Widać to zwłaszcza w ugruntowaniu administracji kościelnej. Biskup Kartaginy Agrypin w 220 roku zwołuje synod, który zgromadził 70 biskupów, a tematem przewodnim była kwestia ważności chrztu udzielanego przez heretyków ${ }^{12}$. Dwadzieścia lat później biskup Donat zwołał drugi synod w 240 roku, w którym uczestniczyło już 90 biskupów ${ }^{13}$. To wszystko ukazuje, że w momentach trudnych, gdy należało stawiać czoła wyzwaniom dyscyplinarnym, biskupi i kler Kościoła afrykańskiego gromadzili się na synodach, aby wspólnie rozwiązywać problemy.

Za czasów posługi pasterskiej św. Cypriana w Kartaginie dość często gromadzili się biskupi i duchowieństwo na synodach: w 251 roku, kiedy rozpatrywano problem upadłych $\mathrm{w}$ czasie prześladowania oraz sprawę schizm Felicissmusa i Nowacjana ${ }^{14}$; w 252 roku, kiedy ponownie rozpatrywano strawę przyjmowania do Kościoła apostatów ${ }^{15}$; w 253 roku synod w Kartaginie zajmował się sprawą chrztu dzieci ${ }^{16}$; w 254 roku synod zajął stanowisko w sprawie Bazylidesa i Marcjalisa złożonych z urzędu za bluź-

11 Ignacy z Antiochii, Ad Ephesios 9, 2, tł. A. Świderkówna, Pierwsi świadkowie, red. M. Starowieyski, BOK 10, Kraków 1998, s. 116.

12 Cyprianus Carthaginensis, Epistula 71, 4, tł. W. Szołdrski, s. 255: „I Agrypin, błogosławionej pamięci, i z innymi współbiskupami, którzy w owym czasie w prowincji Afryce i Numidii rządzili Kościołem Pana, to postanowił i po należytej rozwadze na wspólnej radzie zatwierdził. Ich pobożnego i słusznego rozstrzygnięcia, zbawiennego dla wiary i odpowiedniego dla Kościoła katolickiego, musimy się również trzymać. Abyś zaś wiedział, jaki w tej sprawie list napisaliśmy, przesyłamy ci jego kopię jak również i naszych tamtejszych współbiskupów, kierując się wzajemną miłością".

13 J. Danielou - H.I. Marrou, Historia Kościoła, t. 1, s. 159.

14 Por. G.D. Dunn, The Carthaginian Synod of 251: Cyprian's Model of Pastoral Ministry, w: I concili della cristianità occidentale secoli III-V (XXX incontro di studiosi dell'antichità cristiana, Roma 3-5 maggio 2001), Roma 2002, s. 235-257.

15 Por. J.A. Fischer, Das Konzil zu Karthago im Mai 252, „Annuarium Historiae Conciliorum" 13 (1981) s. 1-11.

16 Por. J.A. Fischer, Das Konzil zu Karthago im Frühjahr 253, „Annuarium Historiae Conciliorum" 13 (1981) s. 12-26. 
nierstwa i idololatrię 17 ; 255 roku uczestnicy synodu zajmowali się sprawą chrztu heretyków ${ }^{18}$; tą samą kwestią zajmowano się również na wiosnę i jesienią $256 \mathrm{roku}^{19}$.

\section{Jedność Kościoła}

Św. Cyprian z Kartaginy, chociaż był człowiekiem bardzo wykształconym i ceniącym przenikliwość Tertuliana, to jednak jako pasterz był ukierunkowany na praktykę duszpasterską i wszystkie problemy pojawiające się we wspólnocie chrześcijan, rozpatrywał je w perspektywie jedności Kościoła, na której straży stał biskup. Wielokrotnie podkreślał autorytet biskupa w Kościele katolickim. Podstawową jego troską było zachowanie jedności Kościoła katolickiego. Każde więc odszczepieństwo o charakterze doktrynalnym i administracyjnym traktował jako atak na jedność Kościoła ${ }^{20}$. Biskup Kartaginy, widząc skrajne postawy wyznawców Chrystusa w swojej wspólnocie dotyczące dyscypliny kościelnej, podkreślał konieczność zgody wobec różnego rodzaju wyzwań, które pojawiły się w trakcie jego duszpasterzowania, a drogą do tego był konsensus wszystkich pasterzy, którzy regularnie spotykali się, aby uzgodnić wspólną linię postępowania. Napisał również traktat De Ecclesiae unitate, w którym podkreśla potrzebę zachowania dyscypliny w łonie wspólnot chrześcijańskich ${ }^{21}$. Wielkim bowiem wyzwaniem były schizmy i herezje we wspólnocie chrześcijan nie tylko w Afryce prokonsularnej ${ }^{22}$, lecz także w innych gminach, zarówno na Wschodzie, jak i na Zachodzie Imperium. Szczególnie wyraźnie uwidoczniło się to na

17 Por. G.D. Dunn, Cyprian of Carthage and the Episcopal Synod of late 254, „Revue des Ėtudes Augustiniennes” 48 (2002) s. 229-247.

18 Por. J.A. Fischer, Das Konzil zu Karthago im Jahr 255, „Annuarium Historiae Conciliorum" 14 (1982) s. 227-240.

19 Por. J.A. Fischer, Das Konzil zu Karthago im Frühjahr 256, „Annuarium Historiae Conciliorum" 15 (1983) s. 1-14.

20 W. Myszor, Zagadnienie herezji w listach św. Cypriana, „Studia Theologica Varsaviensia" 9/1 (1971) s. 187-190.

21 Cyprianus Carthaginensis, De Ecclesiae catholicae unitate 5. Por. Ch.A. Bobertz, The historical context of Cyprian's „De Unitate”, „, The Journal of Theological Studies”, 41/1 (1990) s. 107-111.

22 Por. G.D. Dunn, Heresy and schism according Cyprian of Carthage, „Journal of Theological Studies", 55/2 (2004) s. 551-553; Myszor, Zagadnienie herezji w listach św. Cypriana, s. 147-153. 
skutek działań Felicissimusa i Fortunata w Kartaginie oraz Nowacjana w Rzymie ${ }^{23}$.

O kolegialności biskupów afrykańskich św. Cyprian pisze do św. Korneliusza w odniesieniu do sytuacji, która zaniepokoiła biskupa Rzymu, ponieważ gmina kościelna z Hadrumentum adresowała listy do prezbiterów rzymskich, a nie do niego samego. Biskup Kartaginy wyjaśnia całą sytuację w następujących słowach:

otóż oświadczam ci i zapewniam, że nie stało się to lekkomyślnie ani w zamiarze lekceważenia cię. Po prostu na zebraniu większej liczby tutejszych biskupów postanowiliśmy wysłać do was dwóch naszych kolegów-biskupów: Kaldoniusza i Fortunata, a tymczasem pozostawić wszystko w zawieszeniu, dopóki by nasi wysłannicy nie powrócili i nie donieśli nam albo o zlikwidowaniu już waszych sporów, albo przynajmniej o prawdziwym stanie rzeczy. Ponieważ biskup Polikarp był w tym czasie nieobecny w Hadrumentum, tamtejsi prezbiterzy i diakoni nic jeszcze nie wiedzieli co wspólnie uradziliśmy. Dopiero kiedyśmy tam osobiście przybyli, powiadomiliśmy o powziętej uchwale i odtąd zajęli oni stanowisko takie samo jak inni, by nie wprowadzać rozdźwięku w Kościele ${ }^{24}$.

Św. Cyprian zatem nie tylko próbuje wyjaśnić biskupowi Rzymu dość kłopotliwą sytuację, ale podkreśla, że uchwały zostały podjęte nie przez jednego biskupa, lecz przez wszystkich biskupów zebranych na synodzie oraz to, że prezbiterzy i diakoni Hadrumentum przyjęli jego uchwały, ponieważ wspólnie troszczyli się o jedność w Kościele ${ }^{25}$.

\section{Upadli}

Po zakończeniu prześladowania zarządzonego przez cesarza Decjusza zarówno w Rzymie, jak i w Kartaginie zwołano synody, aby stawić czoła problemowi osób, które załamały się w czasie próby. Sam Cyprian poświęcił temu zagadnieniu osobny traktat De lapsis, którego celem było zachęcanie tych, którzy odpadli od Kościoła w prześladowaniach Decjusza, do poddania się pokucie oczekiwanej przez Kościół, aby mogli być po-

23 E. Dołganiszewska, Extra Ecclesiam nulla salus - Cypriana z Kartaginy myśl o Kościele, „Wrocławski Przegląd Teologiczny” 14/1 (2006) s. 141-157.

24 Cyprianus Carthaginensis, Epistula 48, 2, tł. W. Szołdrski, s. 131-132.

25 P. Mattei, L'ecclésiologie de saint Cyprien. Structures et situation historique, „Connaissance des Pères de l'Église” 96 (2004) s. 15-27. 
jednani ze wspólnotą poprzez nałożenie rąk biskupa i ponowne przyjęcie do Komunii Swiętejej ${ }^{26}$ Podobne stanowisko nie tylko św. Cypriana, lecz znacznej liczby biskupów i kleru afrykańskiego widzimy w relacji zawartej w Liście 56, w którym pisze, że

po rozważeniu „za” i „przeciw” odnośnych tekstów Pisma Świętego, zdecydowaliśmy się obrać drogę pośrednią. Nie chcąc upadłych pozbawiać całkowicie nadziei powrotu do wspólnoty i pokoju, aby nie wpadli w rozpacz i nie wrócili do życia pogańskiego - gdyby Kościół zamknął przed nimi swe bramy $-\mathrm{z}$ drugiej jednak strony nie mając też zamiaru rozluźniać karności ewangelicznej przez zbytnie ułatwianie powrotu do Kościoła, postanowiliśmy przedłużyć o ile możliwości jak najbardziej okres pokuty, następnie żądać wypraszania przebaczenia we łzach i bólu, wreszcie badać w każdym poszczególnym wypadku rodzaj grzechu, usposobienie grzesznika i okoliczności łagodzące ${ }^{27}$.

Z tego fragmentu widać, że św. Cyprian przewodniczył synodowi, którego uczestnicy wypowiedzieli się w podobnym duchu, który reprezentował biskup Kartaginy jako zwolennik drogi pośredniej w kwestii postępowania $\mathrm{z}$ upadłymi podczas prześladowann ${ }^{28}$. Nie każdy bowiem przypadek mógł być traktowany jednakowo ${ }^{29}$.

26 Por. M. Chłopowiec, Aspekty historyczne w rozwoju teologii pokuty okresu patrystycznego do św. Cypriana, „Teologia i Moralność” 3 (2008) s. 191-207; J.H. Tyler, St. Cyprian and the Reconciliation of Apostates, „Theological Studies” 3 (1942) s. 27-46.

27 Cyprianus Carthaginensis, Epistula 56, 2, 1, tł. W. Szołdrski; Acta Synodalia ann. 50-381, s. 6*; L. Misiarczyk - P. Sprusiński, Warunki powrotu lapsi do wspólnoty kościelnej wedtug Cypriana z Kartaginy, „Studia Płockie” 40 (2012) s. 27-48; Zmire, Recherches sur la collégialité épiscopale dans l'Église d'Afrique, s. 27-28; Fischer, Das Konzil zu Karthago im Mai 252, s. 7-11; M. Bévenot, Cyprian's Platform in the Rebaptism Controversy, „Heythrop Journal” 19 (1978) s. 123-142.

28 Por. P. Grattarola, Il problema dei lapsi fra Roma e Cartagine, „Rivista di storia della Chiesa in italia" 38 (1984) s. 1-26; M. Kieling, Kościót wobec idolatrii na podstawie dokumentów Synodów w latach 50-381, VoxP 55 (2010) s. 276-292.

29 Byli bowiem sacrificantes ('ofiarujący'), którzy formalnie składali pogańskim bóstwom ofiary, thurificati ('kadzący'), którzy palili kadzidło, oddając cześć posągom cesarza lub pogańskim bożkom, libellatici, których dzielono na kilka kategorii: niektórzy, zwłaszcza bogaci, za odpowiednią sumę wręczoną skorumpowanym urzędnikom Rzymskim otrzymywali wymagany certyfikat (libellus), że złożyli ofiarę pogańskim bóstwom, jedynie skrajni rygoryści moralni potępiali takie nieuczciwe postępowanie swoich współbraci. Byli i tacy, którzy zapewniali sędziego na piśmie, że zamierzają złożyć bogom ofiarę, lecz w rzeczywistości jej nie składali, inni przesyłali sędziemu niezgodne z prawdą własnoręczne pisemne zapewnienie, że wymaganą edyktem ofiarę złożyli, nie- 
Na synodzie w 251 roku w Kartaginie zostały podjęte uchwały dotyczące upadłych, o czym informuje papieża Korneliusza św. Cyprian w Liście 57. Dotyczą one osób, które chociaż odstąpiły od Chrystusa, to jednak pokutowały przez dłuższy czas i zostały dotknięte chorobą grożącą utratą ich życia. W takim przypadku według zdania uczestników synodu należy im udzielić pokoju. Tym bardziej, że może nadciągnąć następna fala prześladowań.

Nie godziłoby się i ojcowska dobroć, i łaskawość boża nie pozwala, aby pukającym zamykać Kościół, żałującym i proszącym odmawiać nadziei zbawiennej pomocy, schodzących z tego świata odsyłać do Pana bez odzyskanej wspólnoty i pokoju. Sam zresztą pozwolił a nawet wydał prawo, że cokolwiek zostanie związane na ziemi, będzie związane i w niebie, w niebie zaś zostanie rozwiązane to, co tu na ziemi będzie rozwiązane najpierw przez Kościół (por. Mt 16, 19). Uświadamiając sobie z licznych i często powtarzających się znaków, że zbliża się dzień prześladowania, zachęcamy się wzajemnie, abyśmy do walki, którą nam wróg zapowiada, przystąpili uzbrojeni i przygotowani ${ }^{30}$.

Podczas prześladowania Decjusza załamali się nie tylko wierni świeccy, ale w tej grupie znalazło się wielu kapłanów i biskupów, którzy chcieli natychmiast po ustaniu burzy powrócić do sprawowania swoich urzędów. Wielu wiernych i prezbiterów, którzy przetrwali prześladowanie, nie godziło się na taką postawę. W Liście 64 Cyprian odnosi się do sprawy prezbitera przedwcześnie przyjętego do wspólnoty Kościoła. Informuje o uchwałach synodu, w którym uczestniczyło 66 biskupów z charakterystycznym zwrotem: „Cyprian i inni koledzy, zebrani w liczbie 66 na synodzie pozdrawiają brata Fido"31. Biskup Kartaginy pisze do biskupa Bulli, że pomimo dezaprobaty dla lekkomyślności biskupa Terapiusza, który przedwcześnie udzielił rozgrzeszenia prezbiterowi Wiktorowi, szanuje jego czyn i choć

którzy wreszcie wyręczali się pogańskimi przyjaciółmi, którzy w ich imieniu zapewniali sędziego, zresztą niezgodnie z prawdą, że wymagane prawem ofiary zostały złożone i otrzymywali wymagany certyfikat. Por. J.R. Knipping, The libelli of the Decian persecution, „Harvard Theological Review” 16 (1923) s. 345-390; Misiarczyk - Sprusiński, Warunki powrotu lapsi do wspólnoty kościelnej wedtug Cypriana z Kartaginy, s. 27-29.

30 Cyprianus Carthaginensis, Epistula 57, 1, tł. W. Szołdrski, s. 163; Dunn, The Carthaginian Synod of 251: Cyprian's Model of Pastoral Ministry, s. 255-257.

31 Cyprianus Carthaginensis, Epistula 64, tł. W. Szołdrski, s. 214. Por. B. Czyżewski, Postawa św. Cypriana wobec Apostatow na podstawie jego Listów, „Studia Gnesnensia” 17 (2003) s. 185-202; J. Roldanus, No Easy Reconciliation: St. Cyprian on Conditions for Re-integration of the Lapsed, „Journal of Theology for Southern Africa” 92 (1995) s. 23-31. 
udzielił mu surowej nagany, to jednak podkreśla, że pokoju, czyli rozgrzeszenia, którego udzielił prezbiterowi, cofać nie należy $y^{32}$.

List 67 jest relacją z uchwał Synodu z 254 roku, który zajął się bardzo ważną kwestią upadłych biskupów ${ }^{33}$, którzy po ustaniu prześladowania dopominali się odzyskania utraconych stolic biskupich, urząd biskupa sprawowali w Hiszpanii i tam chcieli powrócićs ${ }^{34}$. Zdezorientowani wierni zaapelowali do biskupów afrykańskich. Stanowisko 36 biskupów zebranych na Synodzie było dezaprobatą dla tego typu działań. Odrzucili również łagodniejszą postawę innych biskupów, którzy utrzymywali wspólnotę z upadłymi biskupami Bazylidesem i Marcjalisem, albowiem w ich mniemaniu jest rzeczą niemożliwą sądzić, że karność Bożą można lekceważyć. Odwołując się do licznych tekstów biblijnych, zaznaczyli, że istotną sprawą w otrzymaniu upragnionego przez upadłych kapłanów i biskupów pokoju jest podjęcie pokuty w modlitwie i we łzach. Zebrani na synodzie biskupi wraz ze św. Cyprianem podejmują też w tej sprawie bardzo zdecydowaną uchwałę i komunikują ją wiernym:

ci, którzy ze złymi, z grzesznikami i nie czyniącymi pokuty pozostają w niedozwolonej wspólnocie, kalają się przestawaniem z występnymi, a łącząc się

32 Cyprianus Carthaginensis, Epistula 64, 1, tt. W. Szołdrski, s. 214. Por. Drogosz, Cyprian, biskup Kartaginy wobec swojego kleru (w świetle jego Listów), s. 156157; W.G. Clarke, Cyprian's Epistle 64 and the Kissing of Feet in Baptism, „Harvard Theological Review" 66/1 (1973) s. 147-152.

33 Problem ten dotyczył wielu biskupów w wielu prowincjach Imperium. W korespondencji św. Cypriana znajdujemy m.in. odpowiedź na List biskupa Epikleta, który skarży się na swego poprzednika roszczącego sobie pretensje do utraconego urzędu po swoim załamaniu się podczas prześladowania. Por. Cyprianus Carthaginensis, Epistula 65, 1, tt. W. Szołdrski, s. 217: „Bardzo boleśnie, najdrożsi bracia, dotknęła mnie wiadomość, że Fortunation, były wasz biskup, po wielkim swoim upadku chce uchodzić za niewinnego i rości sobie pretensje do ponownego objęcia biskupstwa [...]. Ten biedak albo przez szatańskie ciemności całkowicie zaślepiony albo czyjąś świętokradzką namową oszukany, mimo że powinien zadośćuczynić i dla przebłagania Pana dniami i nocami oddawać się łzom, modlitwom i prośbom, teraz odważa się domagać kapłaństwa, które utracił; jakby to było godziwe od stołów ofiarnych diabła przystąpić do ołtarza Boga". Por. M. Wysocki, Przebaczenie w pismach św. Cypriana z Kartaginy, „Verbum Vitae” 18 (2010) s. 187-211.

34 Cyprianus Carthaginensis, Epistula 67, 1, tł. W. Szołdrski, s. 227: „donieśliście, że Bazylides i Marcjalis skalali się zaświadczeniem, że złożyli bożkom ofiary i mając obciążone sumienie haniebnymi występkami, nie mogą sprawować urzędu biskupiego i kapłaństwa Boga. Pragnęliście, aby wam odpisać i w tej waszej słusznej, a zarazem koniecznej trosce albo was pocieszyć, albo też wesprzeć naszą radą. Na to wasze pragnienie nie tyle odpowiadają nasze rady, co raczej nakazy boże". 
z nimi w popełnieniu winy i co do kary nie są od nich odłączeni. Dlatego, najukochańsi bracia, waszą nienaruszoną wiarę i pobożną o jej zachowanie troskę chwalimy i uznajemy i jak tylko możemy, zachęcamy was naszym listem, abyście z bezbożnymi i skalanymi kapłanami nie pozostawali w świętokradzkiej wspólnocie, lecz całkowitą i nieskończoną stałość waszej wiary zachowujcie z pobożną bojaźnią ${ }^{35}$.

Wydaje się, że św. Cyprian sądził, że jego pasterska odpowiedzialność za wyznawców Chrystusa rozciągała się z Kartaginy na prowincje rzymskiej Afryki Północnej i była dzielona z jego kolegami, innymi biskupami afrykańskimi gromadzacymi się na wspólne obrady na zwoływanych stosunkowo często synodach. Poza tymi granicami Św. Cyprian z Kartaginy swój pasterski obowiązek postrzegał jako wspieranie jedności Kościoła, uznając autorytet legalnie ustanowionych lokalnych biskupów. Jego katolickim obowiązkiem duszpasterskim nie było przeważanie nad obowiązkami lokalnych biskupów, lecz ich wspieranie ${ }^{36}$.

\section{Schizmy Felicissimusa i Nowacjana}

Kościół afrykański rozwijał się w tym okresie dość prężnie, lecz jego stan pod względem dyscypliny wewnętrznej pozostawiał wiele do życzenia. Jak napisał Cyprian, Kościół cieszył się długim pokojem (pax longa), który znacznie osłabił zapał i dyscyplinę wielu jego członków ${ }^{37}$. Ucierpiał nawet autorytet episkopatu afrykańskiego ${ }^{38}$. Wielu biskupów zajmowało się rolnictwem lub handlem, a w niektórych przypadkach nawet lichwą. Wystąpiły wśród nich przypadki nadużyć nielicujących z radami ewangelicznymi, które stanowiły o chrześcijańskim stylu życia. Czasami byli tak bardzo nieuformowani, że nie mogli właściwie nauczać katechumenów ani nie potrafili rozróżniać ortodoksyjnych i heretyckich doktryn. W takich okolicznościach nawrócenie takiego człowieka, którym był św. Cyprian, było sporą sensacją i rozbudziło wielkie oczekiwania we wspólnocie chrześcijan w Afryce prokonsularnej. W 248 roku stolica biskupia

35 Cyprianus Carthaginensis, Epistula 67, 9, tł. W. Szołdrski, s. 233.

36 Dunn, Cyprian of Carthage and the Episcopal Synod of late 254, s. 239-247.

37 Cyprianus Carthaginensis, De lapsis 5, 1, 1: „Dominus probari familiam suam voluit; et quia traditam nobis, divinitus discjplinam pax longa corrupert, iacentem fidem et pene, ut ita dixerim, dormientem - censura coelestis erexit”. Por. S. Sroka, Nauka św. Cypriana o miłosierdziu chrześcijańskim, Tarnów 1939, s. 6.

38 Por. Bobertz, The Historical Context of Cyprian's „,De Unitate”, s. 107-111. 
w Kartaginie została osierocona i właśnie Cecyliusz Cyprian został wybrany na pasterza tej wspólnoty wyznawców Chrystusa. Charakterystyczne jest jednak to, że wybór Cypriana na biskupa Kartaginy nie dokonał się jednomyślnie. Od samego początku część prezbiterium przeciwstawiała się temu wyborowi. Po jego konsekracji opozycja nie przestała istnieć, wręcz przeciwnie, stronnictwo to stało się bardziej zorganizowane i gdy na początku 250 roku rozpoczęły się prześladowania zainicjowane edyktem Decjusza, przeciwnicy Cypriana zaatakowali go na wieść, że nowy biskup, chroniąc się na wsi, uniknął uwięzienia ${ }^{39}$. Wśród chrześcijan rozeszła się wieść, że Cyprian uciekł. Nie wystarczało to, że ze swoją wspólnotą utrzymywał kontakt, umacniał wiernych $\mathrm{w}$ wierze i znoszonych trudach oraz przeznaczał wielkie środki na wsparcie najuboższych ${ }^{40}$.

Po powrocie do Kartaginy św. Cyprian musiał wiele wyjaśniać najpierw w 252 roku biskupowi Rzymu, Korneliuszowi (List 59), a nawet jeszcze w 254 roku napisał list do Florencjusza, odpierając stawiane mu zarzuty i prosząc o jego wstawiennictwo oraz wsparcie. W tym ostatnim liście z goryczą odnosi się do krzywdzących opinii dotyczących jego osoby, a rozpowszechnionych przez jego przeciwników:

Niektórzy z pyszną zarozumiałością gardzą biskupem, który jest jeden i przewodniczy Kościołowi, i człowieka, którego Bóg uczcił, ludzie uważają za niegodnego. Jakaż to nadęta pycha, jaka zarozumiałość ducha, jaka napuszoność umysłu, zwierzchników i kapłanów przed swój sąd powoływać! Jeślibyśmy przez ciebie nie zostali oczyszczeni i usprawiedliwieni twym wyrokiem, to oto już przez sześć lat wierni nie mieliby biskupa, Chrystus zastępcy, Bóg kapłana. Niechaj Puppian [przydomek Cypriana] pomoże, wyda wyrok, sąd Boga i uzna Chrystusa, aby się nie zdawało, że tak wielka liczba wiernych,

39 Por. M. Bévenot, The Sacrament of Penance and St. Cyprian's „De Lapsis”, „Theological Studies” 16 (1955) s. 175-213; Bobertz, The Historical Context of Cyprian's „De Unitate”, s. 107-111; G.D. Dunn, Cyprian and His Collegae: Patronage and the Episcopal Synod of 252, „Journal of Religious History” 27/1 (2003) s. 1-13; G.D. Dunn, Validity of Baptism and Ordination in the African Response to the "Rebaptism» Crisis: Cyprian of Carthage's Synod of Spring 256, „Theological Studies” 67 (2006) s. 257-274; H.G. Hall, The Versions of Cyprian's De Unitate 4-5: Bevenot's Dating Revisited, „Journal of Theological Studies" 55/1 (2004) s. 138-146.

40 Por. S. Strękowski, Troska pasterza i wspólnoty kościelnej w Kartaginie o rodzinę w pierwszej połowie III wieku, w: Wsparcie rodziny wyzwaniem dla Kościoła i społeczeństwa, red. W. Guzewicz - J. Łodzińska - A. Mikucki - S. Strękowski, Ełk 2016, s. 247270; S. Strękowski, Prorodzinne i prospołeczne postawy i działania chrześcijan w świecie jako wkład w budowanie dobra wspólnego w I-III wieku, „Civitas et Lex” 4/16 (2017) s. 74-76. 
których przyjęliśmy, umiera bez nadziei zbawienia i pokoju, żeby nie uważano, że nowy lud wiernych nie otrzymał przez nas żadnej łaski chrztu i Ducha Świętego, żeby tylu upadłym i pokutnikom po zbadaniu sprawy udzielony pokój i przyjęcie ich przez nas do wspólnoty tym orzeczeniem nie zostały unieważnione. Zechciej się przychylić, łaskawie o nas się wyrazić i mocą twego oświadczenia potwierdź nasze stanowisko biskupie, aby Bóg i Jego Chrystus mogli ci za to dziękować, że dzięki tobie zwierzchnik i kierownik do ich ołtarza, a zarazem ludowi został przywrócony ${ }^{41}$.

W tym kontekście łatwiej jest zrozumieć działania św. Cypriana z Kartaginy na rzecz kolegialności i zwoływanych przez niego synodów. Nie tylko tradycja zwoływania ich, lecz także wymóg trudnych czasów jest ważnym elementem troski o zachowanie jedności we wspólnotach kościelnych, dzięki wspólnie wypracowanym decyzjom ${ }^{42}$.

Św. Cyprian z bólem dowiedział się o odstąpieniu diakona Felicissimusa od jedności kościelnej i w Liście 41 z 251 roku, gdy przebywał jeszcze poza Kartaginą, tak pisze na wieść o schizmie:

tymczasem donosicie mi teraz, że Felicissimus postępuje bardzo niegodziwie i podstępnie. Poza oszustwami i grabieżami, o których już przedtem dużo wiedziałem, teraz podburza część ludu przeciw biskupowi, to jest chce odłączyć pasterza od owiec, oddzielić synów od ojca i rozproszyć członki Chrystusa ${ }^{43}$.

Nadmienia dalej, że diakon Felicissimus odmówił udzielenia pomocy materialnej osobom potrzebującym, którą przesłał św. Cyprian przez jego współpracowników. Ponadto zagroził, że nie przyjmie pokutujących do wspólnoty, nawet gdyby groziła im śmierć, jeśli nadal będą posłuszni prawowitemu biskupowi. Zapowiada również, że

wszystko zbadamy, gdy Pan pozwoli, że zgromadzimy się wspólnie z wieloma kolegami. Również i Augendus, który nie zważając na biskupa i na Kościół, dołączył się do owego spisku, jeśli przy nim pozostanie, taką samą poniesie karę, jaką ten żądny władzy zuchwalec na siebie ściąga. Podobnie każdy, kto się do jego spisku i partii dołączy, niechaj wie, że nie jest z nami w Kościele złączony ten, kto chciał się dobrowolnie od Kościoła odłączyć. Ten mój list

${ }^{41}$ Cyprianus Carthaginensis, Epistula 66, 5, tt. W. Szołdrski, s. 223.

42 Por. Myszor, Zagadnienie herezji w listach św. Cypriana, s. 147-151.

43 Cyprianus Carthaginensis, Epistula 41, 1, tł. W. Szołdrski, s. 117-118; P. Grattarola, Gli scismi di Felicissimo e di Novaziano, „Rivista di Storia della Chiesa in Italia" 38 (1984) s. 367-390. 
przeczytajcie naszym braciom i roześlijcie go klerowi w Kartaginie z dodaniem imion tych, którzy się do Felicissimusa przyłączyli4 ${ }^{44}$.

Warto zaznaczyć, że diakon Felicissimus w Kartaginie przewodził grupie pięciu prezbiterów, którzy sprzeciwiali się prawowitemu wyborowi św. Cypriana na stolicę biskupią w Kartaginie w 249 roku i w czasie prześladowań znaleźli oni - według ich mniemania - odpowiedni pretekst, aby wymówić mu posłuszeństwo. Sam Felicissimus był raczej duchowym przywódcą tego stronnictwa, a jako konkurencyjnego biskupa dla św. Cypriana wysunął Fortunata, jednego z owych pięciu prezbiterów, którzy krytykowali działania legalnie wybranego biskupa ${ }^{45}$.

W następnych listach $(43,48)$ przestrzega wiernych przed pokusą przyłączenia się do niebezpiecznej dla jedności Kościoła w Kartaginie schizmy Felicissimusa, wyraża swoją wielką radość, że wielu schizmatyków powraca do wspólnoty oraz informuje Korneliusza, biskupa Rzymu o działaniach Nowacjana, antypapieża, który w Afryce prokonsularnej zabiegał o przeciągnięcie na swoją stronę jak największej ilości wiernych, pomimo tego, że posiadał już swoich zwolenników w Galii i na Wschodzie Imperium ${ }^{46}$.

Nowacjan, kapłan rzymski, i Nowat, kapłan z Kartaginy, który jednak początkowo głosił odmienne ${ }^{47}$, wręcz przeciwne poglądy niż rygorysta znad Tybru, to jednak w późniejszym okresie przyłączył się do Nowacjana i wspólnie z nim toczył spór z papieżem Korneliuszem i biskupem Cyprianem w sprawie ponownego przyjęcia do wspólnoty kościelnej osób, które $-\mathrm{z}$ różnych powodów - złożyły nakazane edyktem cesarza Decjusza ofiary pogańskim bożkom podczas prześladowania ${ }^{48}$. W obliczu rozszerzającej się schizmy Nowacjana nie tylko w Rzymie, lecz także poza nim również papież Korneliusz w 251 roku zwołał synod, w którym wzięło

44 Cyprianus Carthaginensis, Epistula 41, 2, tł. W. Szołdrski, s. 119. O wykluczeniu ze wspólnoty kościelnej w Kartaginie informuje św. Cyprian w Liście 42 z 251 roku (tł. W. Szołdrski, s. 119) Kaldoniusza, Wiktora oraz prezbiterów Rogacjana i Numidyka: „ze wspólnoty wykluczyliśmy Felicimussa i Augenda, oraz Reposta i Irenę z Rutilów, Paulę krawcową. O tym powinieneś wiedzieć z mej notatki. Wykluczyliśmy również Sofroniusza i wygnanego Soliasuma".

45 Drogosz, Cyprian, biskup Kartaginy wobec swojego kleru (w świetle jego Listów), s. 161-162; Grattarola, Gli scismi di Felicissimo e di Novaziano, s. 367-371.

46 Nowacjanie, w: H. Masson, Słownik herezji w Kościele katolickim, tł. B. Sęk, Katowice 1993, s. 228; Por. M. Szram, Nowacjanie, w: EK XIV 26.

47 Por. M. Wysocki, Nowat, w: EK XIV 42.

48 Por. Szram, Nowacjanie, k. 26. 
udział 60 biskupów ${ }^{49}$. Oznacza to, jak wielką wagę przywiązywano do kolegialności biskupów nie tylko w Kartaginie, lecz także w Rzymie i innych prowincjach kościelnych.

Dowiedziawszy się o schizmie Nowacjana i jego działalności w Afryce prokonsularnej, św. Cyprian, podkreślając wagę jedności Kościoła, szczególnie w obliczu ciągle grożacych prześladowań, udziela informacji biskupowi Antoniuszowi (List 55) w tej sprawie, tak charakteryzując szkodliwe działania schizmatyka:

kimkolwiek i jakimkowiek jest, na pewno nie jest chrześcijaninem ten, kto nie jest w Kościele Chrystusa. Może się chełpić a swą filozofię i wymowę pysznymi słowy głosić: kto jednak nie trzyma się braterskiej miłości i jedności kościelnej, ten utracił i to, czym był poprzednio. Czyż uważasz za biskupa, który, pomimo iż szesnastu innych współbiskupów w Kościele ustanowiło tamtego, a on w swej ambicji stara się, aby go odstępcy ustanowili fałszywym, poza Kościołem i biskupem. A chociaż od Chrystusa pochodzi jeden Kościół, który na całym świecie dzieli się na wielu członków, i jest jeden episkopat, na który się składa wielka liczba działających wspólnie biskupów, to jednak on [Nowacjan] wbrew boskiej tradycji, wbrew zwartej i wszędzie istniejącej jedności Kościoła katolickiego, stara się założyć Kościół ludzki i do wielu miast wysyła swych nowych apostołów, aby dla swej działalności utworzyć nowe podstawy ${ }^{50}$.

\section{Kwestia ważności chrztu udzielanego przez heretyków}

Św. Cyprian w Liście 70 wymienia imiona 31 zebranych w 255 roku uczestników Synodu i odwołuje się do formuły chrzcielnej oraz pytania, które zadawane było przy udzielaniu tego sakramentu: „czy wierzysz w życie wieczne i odpuszczenie grzechów przez Kościół święty?’51. „I zaznacza, że odpuszczenie grzechów może być udzielone tylko

49 Nowacjanie, w: H. Masson, Stownik herezji w Kościele katolickim, s. 228; Grattarola, Gli scismi di Felicissimo e di Novaziano, s. 367-371.

50 Cyprianus Carthaginensis, Epistula 55, 24, t1. W. Szołdrski, s. 156-157; Grattarola, Gli scismi di Felicissimo e di Novaziano, s. 367-371.

51 Cyprianus Carthaginensis, Epistula 70, 2, Acta Synodalia ann. 50-381, s. 23*. Por. P. Mattei, Les frontières de l'Église selon la première tradition africaine (Tertullien, Cyprien, Anonyme De rebaptismate), „Revue des Sciences Religieuses” 81 (2007) s. 27-47. 
w Kościele, u heretyków zaś, którzy nie są w kościele, nie ma darowania grzechów" 52 .

Następnym argumentem za tym, że tylko w Kościele dokonuje się odpuszczenie grzechów, są dla św. Cypriana cytaty biblijne zaczerpnięte ze Starego Testamentu, choć wówczas w starożytnym Izraelu praktyka chrztu nie była znana. Cyprian odnosi się do ,źródta wody żywej i czystej" (Jr 2,13; Ez 36,25-26; Lb 19,22) ${ }^{53}$, którym jest sam Bóg. Jednym z istotnych elementów jest dar Ducha Świętego, który jest dany w sakramencie chrztu. Św. Cyprian zaznacza, że

zadowalać się chrztem heretyków i schizmatyków, znaczy go uznawać. Nie może bowiem tu jednak część być bezskuteczna, a druga skuteczna. Gdyby ktoś mógł udzielać chrztu, mógłby też dać Ducha Świętego. Ponieważ jednak Ducha Świętego udzielić nie może, bo jest poza Kościołem i nie posiada Ducha Świętego, nie może też ochrzcić tego, kto do niego przychodzi. Jest bowiem tylko jeden chrzest, jeden Duch Święty (Ef 4, 4-5) i jeden Kościół, który Pan nasz Jezus Chrystus, jako jeden i co do jego początku i ustroju na Piotrze założył ${ }^{54}$.

Św. Cyprian stawia retoryczne pytanie odnosząc się do łaski przebaczenia grzechów, która jest konsekwencją przyjmowanego sakramentu chrztu świętego: ,jakże udzielający chrztu może innemu przebaczyć grzechy, skoro sam poza Kościołem swych grzechów pozbyć się nie zdoła?"55.

Dopiero św. Augustyn z Hippony sformułował zasadę, że sakrament działa mocą samego Chrystusa, a nie mocą świętości szafarza ${ }^{56}$.

52 Cyprianus Carthaginensis, Epistula 70, 2. Por. Myszor, Zagadnienie herezji w listach św. Cypriana, s. 187-190.

53 Cyprianus Carthaginensis, Epistula 70, 1, 1-3, Acta Synodalia ann. 50-381, s. 22*. Por. K. Shuve, Cyprian of Carthage's Writings from the Rebaptism Controversy: Two Revisionary Proposals Reconsidered, „Journal of Theological Studies” 61/2 (2010) s. 627-643.

54 Cyprianus Carthaginensis, Epistula 70, 3, 1, Acta Synodalia ann. 50-381, s. 23*25*. Por. M. Bévenot, „Primus Petro Datur”: St. Cyprian on the Papacy, „Journal of Theological Studies" 5 (1954) s. 19-35.

55 Cyprianus Carthaginensis, Epistula 70, 1, 3, Acta Synodalia ann. 50-381, s. 22*. Por. J.P. Burns, On Rebaptism: Social Organization in the Third Century Church, ,Journal of Early Christian Studies" 1 (1993) s. 367-403.

56 Aurelius Augustinus, De Civitate Dei, 21, 20, tł. W. Kubicki, Św. Augustyn, O Państwie Bożym, Poznań 1937, s. 528: „Znowu niektórzy obiecują to odpuszczenie kary wiecznej nie wszystkim dostępującym chrztu Chrystusowego i sakramentu ciała Jego, lecz samym tylko katolikom, choćby nie wiem jak źle żyli, ponieważ ci nie tylko 
W tej samej kwestii zachowały się akta synodu z września 256 roku, w którym zanotowane zostały wypowiedzi 87 biskupów pochodzących nie tylko z Arfyki, lecz także z Numidii, Mauretanii oraz prezbiterzy i diakoni, którzy jednogłośnie opowiedzieli się za nieważnością chrztu heretyków. Gdy wszyscy wyrazili swoją opinię po wcześniejszym odczytaniu korespondencji Cypriana z biskupem Jubajanem, biskup Kartaginy podsumował wszystkie wypowiedzi uczestników synodu w sposób jednoznaczny wyrażający dezaprobatę dla chrztu heretyków ${ }^{57}$.

Euzebiusz z Cezarei w swojej Historii kościelnej zamieszcza bardzo lakoniczną wiadomość dotyczącą wzajemnych relacji Cypriana i biskupa Rzymu Stefana dotyczących kwestii powtórnego chrztu powracających do Kościoła heretyków. Tak pisze:

Spośród ówczesnych biskupów przede wszystkim Cyprian, pasterz Kościoła kartagińskiego, uważał, że należy przyjmować tylko tych, którzy ze swego obłędu zostali oczyszczeni przez chrzest. Tymczasem Stefan, który stał na stanowisku, że nie wolno wprowadzać żadnych nowinek niezgodnych z prastarą tradycją, oburzał się na takie postępowanie ${ }^{58}$.

Jednak pomimo kontrowersji do zerwania łączności z Kościołem rzymskim nie doszło ${ }^{59}$, albowiem pomimo gorzkich słów skierowanych do papieża Stefana przez św. Cypriana w sprawie ważności chrztu heretyków

\footnotetext{
w sakramencie, lecz też w rzeczywistości (re ipsa) spożywali ciało Chrystusowe, jako umieszczeni w jego ciele, o którem mówi Apostoł: «Jeden chleb, jedno ciało, nas wiele jesteśmy». Tacy, chociażby później wpadli w herezję jaką, albo nawet w bałwochwalstwo pogańskie - skoro tylko w ciele Chrystusowem, czyli w Kościele katolickim przyjęli chrzest Chrystusowy i spożywali ciało Chrystusowe, nie umrą na wieki - lecz wcześniej, czy później, żywota wiecznego dostąpią". Por. P. van Geest, Pectus ardet Evangelica pietate, et pectori respondet oratio: Augustine's Neglect of Cyprian's Striving for Sincerity, w: Cyprian of Carthage: Studies in His Life, Language, and Thought, red. H. Bakker P. van Geest - H. van Loon, Leuven 2010, s. 203-224.

57 Acta Synodalia ann. 50-381, s. 27*-41*.

58 Eusebius Caesarensis, Historia Ecclesiastica VII 3, tł. A. Caba, Euzebiusz z Cezarei, Historia Kościelna, tekst grecki i polski, ŹMT 70, Kraków 2013, s. 481.

59 Por. Myszor, Zagadnienie herezji w listach św. Cypriana, s. 150: „Stefan biskup rzymski narzucając innym biskupom swoją naukę o chrzcie heretyków zdaniem Cypriana wyłamuje się z tej jedności, chce być biskupem biskupów. Jeśli Cyprian nie nazwał tego herezją, to chyba dlatego, że proces nieporozumień między Kartaginą a Rzymem nie doszedł do tego stopnia. Wszystko wskazuje na to, że odpowiednikiem mistycznej jedności Ducha św. w Kościele powszechnym jest jedynie moralny obowiązek dbania o jednomyślność i wzajemną zgodę wśród biskupów. W takim ujęciu również trudno mówić o jakichś czynnikach odróżniających herezję od schizmy”.
} 
z 256 roku (List 74), w roku 258 biskup Kartaginy pisze do Sukcesa o zamiarach cesarskich względem chrześcijan następujące słowa, które wyrażają solidarność z biskupem Rzymu i jego współpracownikami:

do swego dekretu Walerian dołączył jeszcze kopię pisma, jakie w naszej sprawie wysłał do namiestników prowincji. Codziennie spodziewamy się nadejścia tego pisma. Gotowi jesteśmy, opierając się na mocy wiary, poddać się męce i oczekujemy od pomocy i łaskawości Pana korony wiecznego życia. Wiedzcie, że Sykstus [następca papieża Stefana I] 6 sierpnia został zabity na cmentarzu, a z nim czterech diakonów. Prefekci w Mieście [Rzymie] tym prześladowaniem codziennie gorliwie się zajmują. Wszyscy, których im wskazują, śmierć ponoszą, a ich majątek zabiera skarb państwowy. Proszę, abyście o tym donieśli i innym kolegom, aby wszędzie za ich zachętą wierni byli umocnieni i przygotowani do duchowej walki, aby każdy z naszych nie tyle myślał o śmierci, co o nieśmiertelności; żeby wszyscy pełni wiary i niewzruszonej odwagi, oddani Bogu, bardziej cieszyli się tym wyznaniem, niż się go obawiali. Przecież wiedzą, że żołnierze Boga i Chrystusa nie giną, lecz otrzymują koronę ${ }^{60}$.

Te słowa biskupa Kartaginy są bardzo znamienne, albowiem ukazują eschatologiczną perspektywę dla wyznawców Chrystusa w obliczu nieuchronnego prześladowania, podczas którego wszyscy są wezwani do złożenia świadectwa ${ }^{61}$.

\section{Chrzest dzieci}

Chrzest dzieci we wspólnotach kościelnych znany był od pierwszego wieku, o czym może świadczyć przypadek Polikarpa, biskupa Smyrny, który przed śmiercią, mając 86 lat - jak donosi autor dokumentu o jego męczeństwie - miał odpowiedzieć na żądanie urzędnika, aby złorzeczył Chrystusowi, że „86 lat Mu służę i nic mi złego nie uczynił, dlaczego mam Mu złorzeczyć?"’2. Był zatem ochrzczony jako dziecko, lecz problem doty-

60 Cyprianus Carthaginensis, Epistula 80, 1-2, tł. W. Szołdrski, s. 306-307.

61 Por. M. Wysocki, Eschatologiczna nagroda w pismach św. Cypriana, „Roczniki Historii Kościoła" 56/1 (2009) s. 33-48.

62 Martyrium Polycarpi 18, 3; M. Pastuszko, Dzieci jako podmiot chrztu, „Prawo Kanoniczne: Kwartalnik prawno-historyczny” 22/1-2 (1979) s. 95-96. Por. obszerne opracowania dotyczące sakramentu chrztu świętego i chrztu dzieci w Kościele starożytnym: J.Ch. Didier, Le baptême des enfants dans la tradition de l'Église, Tournai 
czący wspólnoty chrześcijan w Afryce prokonsularnej dotyczył niemowląt. W Liście 64 relacjonującym uchwały synodu w Kartaginie ${ }^{63}$ znajdujemy uchwałę dotyczącą sakramentu chrztu udzielanego niemowlętom tuż po ich urodzeniu. Sw. Cyprian w przeciwieństwie do swego mistrza Tertuliana, który opowiadał się za odwlekaniem chrztu ${ }^{64}$, zaznacza, że jest to wspólnie uzgodnione na synodzie (prawdopodobnie w 252 roku) stanowisko i przeciwko opinii Fidusa, adresata Listu, biskup Kartaginy w imieniu wszystkich uczestników synodu oznajmia:

co się tyczy chrztu dzieci, to powiedziałeś, że w drugim lub w trzecim dniu po ich urodzeniu chrzcić ich nie należy i że trzeba uwzględnić dawne prawo obrzezania i dlatego przed ósmym dniem chrzcić i uświęcać się nie powinno. Nasz synod co do tego był całkowicie innego zdania. Na twój pogląd nikt się nie zgodził, lecz raczej wszyscy sądziliśmy, że żadnemu urodzonemu dziecku nie można odmawiać miłosierdzia Boga i łaski. Pan przecież mówi w swej ewangelii: „Syn Człowieczy nie przyszedł zatracać dusze ludzi, lecz zbawiać" (por. Łk 9, 56), i o ile to jest w naszej mocy, powinniśmy się starać, aby nie zginęła żadna dusza ludzka. Cóż bowiem brakuje temu, kto raz w łonie matki został utworzony rękami Boga? Tylko w naszych oczach z biegiem

1959; J. Jeremias, Die Kindertaufe in den ersten vier Jahrhunderten, Göttingen 1958; E. Ferguson, Baptism in the Early Church: history, theology and liturgy in the first five centuries, Cambridge 2009; T.M. Finn, Early Christian Baptism and the Catechumenate: Italy, North Africa and Egypt, Collegeville 1992; H. Pietras, Jeden chrzest na odpuszczenie grzechów - próba zrozumienia świadectw patrystycznych, w: Kościót, świat i zbawienie we wczesnym chrześcijaństwie, red. J. Naumowicz, Warszawa 2004, s. 179-193.

63 Por. Pastuszko, Dzieci jako podmiot chrztu, s. 98; Fischer, Die Konzilien zu Karthago und Rom in Jahr 251, s. 263-286.

64 Tertullianus, De Baptismo 18, w: J. Słomka, Chrzest i pokuta w Kościele starożytnym. Antologia tekstów I-III w., Kraków 2004, s. 171: „dlatego jest rzeczą korzystniejszą stosownie do warunków i dyspozycji każdej osoby, a zwłaszcza stosownie do wieku, odkładanie chrztu, szczególnie jednak, gdy chodzi o dzieci. Czy jest bowiem konieczne narażać rodziców chrzestnych na niebezpieczeństwo, skoro jest możliwe, że mogą nie dotrzymać swych obietnic, czy to z powodu śmierci, czy też sprawić zawód z powodu słabych zdolności wychowawczych? Pan istotnie powiedział: «Nie przeszkadzajcie im przychodzić do Mnie» (Mt 19, 14). Niech przeto przychodzą, gdy dorosną, gdy zaczną się uczyć. Niech przychodzą, gdy zostaną pouczeni, dokąd mają iść. Niech będą chrześcijanami wówczas, gdy poznają Chrystusa. Dlaczego wiek niewinny tak bardzo pragnie odpuszczenia grzechów? Czy w sprawach doczesnych nie postępuje się o wiele przezorniej, skoro dobra duchowe powierza się temu, komu jeszcze nie przekazuje się majątku ziemskiego? Niech nauczą się prosić o zbawienie, by zrozumieli, że otrzymali, ponieważ prosili”. Por. Pastuszko, Dzieci jako podmiot chrztu, s. 97. 
dni rosną ci, którzy się urodzili. Wszystko jednak, co Bóg stworzył, jest doskonałe, dzięki majestatowi i działalności Boga Stworzyciela ${ }^{65}$.

Ustosunkowując się do argumentacji Fidusa, obala każdy element, odwołując się do zdrowego rozsądku i cytatów biblijnych. Wreszcie podsumowując całą argumentację przemawiającą za udzielaniem sakramentu chrztu również niemowlętom, oznajmia biskupowi Fidusowi uchwałę synodu:

postanowiliśmy na naszym synodzie, że nie można komukolwiek odmawiać chrztu i łaski Boga, który dla wszystkich jest miłosierny, dobry i łaskawy. Jeśli względem wszystkich należy to zachowywać i tego się trzymać, to tym bardziej, jak sądzimy, odnośnie dzieci i noworodków. Te tym bardziej zasługują na naszą pomoc i miłosierdzie Boga, ponieważ przy swym urodzeniu nic innego nie czynią, tylko proszą kwileniem i płaczem ${ }^{66}$.

Jak z tego widać, nie jest to stanowisko jedynie św. Cypriana, lecz wszystkich zebranych na synodzie biskupów. Jego informacja jest powiadomieniem o powziętej wspólnie decyzji.

\section{Zakończenie}

W połowie III wieku biskupem Kartaginy w Afryce prokonsularnej został wybrany Thascius Caecilius Cyprianus, człowiek zamożny i gruntownie wykształcony. W czasie prześladowań zarządzonych przez cesarza Decjusza wiara wielu osób została poddana ciężkiej próbie. We wspólnocie chrześcijan powstały podziały na tle dyscyplinarnym i administracyjnym. Św. Cyprian odwołał się do starej tradycji pielęgnowanej nie tylko w Kościele Afryki prokonsularnej, lecz także w innych prowincjach Kościoła powszechnego, którą było zwoływanie synodów w celu wspólnego rozwiązywania powstałych problemów duszpasterskich. W czasach zasiadania na stolicy biskupiej w Kartaginie św. Cyprian zwołał 7 synodów, których uczestnicy zajęli swoje stanowisko wobec schizm Felicissimusa i Nowacjana oraz w sprawie powrotu do wspólnoty kościelnej osób, które uległy nakazom edyktu Decjusza, dokonując ofiar bałwochwalczych, waż-

65 Cyprianus Carthaginensis, Epistula 64, 2, tł. W. Szołdrski, s. 215; Pastuszko, Dzieci jako podmiot chrztu, s. 98.

66 Cyprianus Carthaginensis, Epistula 64, 6, tł. W. Szołdrski, s. 217; Pastuszko, Dzieci jako podmiot chrztu, s. 98. 
ności chrztu udzielanego przez heretyków oraz chrztu dzieci. Nie wszystkie decyzje synodalne były akceptowane przez wszystkie prowincje. Nie wszystkie uchwały synodów w Kartaginie współtworzyły doktrynę Kościoła. Przykładem może być uchwała o nieważności chrztu udzielanego przez heretyków, co stało się powodem do polemiki Cypriana z biskupem Rzymu, Stefanem - do rozłamu nie doszło, lecz odmienne uchwały funkcjonowały $\mathrm{w}$ różnych prowincjach. Widocznym celem takich postanowień była troska o zachowanie jedności Kościoła. Św. Cyprian, szanując autonomię każdego biskupa w zarządzaniu swoją wspólnotą, starał się wypracować wspólną linię postępowania, mając na uwadze zachowanie jedności Kościoła katolickiego.

\title{
Synods in Proconsular Africa of the Third Century as a Manifestation of the Collegiality of Bishops in the Light of the Synodal Canons and Letters of St. Cyprian of Carthage
}

\author{
(summary)
}

In the mid-third century, Thascius Caecilius Cyprianus, a wealthy and educated man, was elected bishop of Carthage in proconsular Africa. During the persecution ordered by Emperor Decius, the faith of many people was put to the test. Disciplinary and administrative divisions arose in the Christian community. St. Cyprian appealed to the old tradition cultivated not only in the Church of proconsular Africa, but also in other provinces of the universal Church, which was the convening of synods in order to solve together pastoral problems. During the time of sitting on the episcopal capital in Carthage, a total of 7 synods were convened, whose participants took their stand on the schism of Felicissimus and Novatian, and on the return to the church community of persons who were subject to the decree of Decius by making idolaters, the validity of baptism by heretics and baptism children. This study is an attempt to show the important role of synods in shaping the collegiality of bishops in proconsular Africa in the mid-third century in the context of concern for the unity of the Church.

Keywords: Cyprian of Carthage; synods; episcopal colleges; schisms; heresies

\section{Sinodi nell'Africa proconsolare del terzo secolo come l'espresione della collegialità dei vescovi alla luce dei canoni sinodali e delle lettere di San Cipriano di Cartagine}

\author{
(riassunto)
}

A metà del terzo secolo, Thascius Caecilius Cyprianus, un uomo ricco e istruito, fu eletto vescovo di Cartagine nell'Africa proconsolare. Durante la persecuzione ordinata dal 
peratore Decio, la fede di molte persone fu messa alla prova. Divisioni disciplinari e amministrative sorsero nella comunità cristiana. San Cipriano si appellò alla vecchia tradizione coltivata non solo nella Chiesa dell'Africa proconsolare, ma anche in altre province della Chiesa universale, che era la convocazione dei sinodi per risolvere insieme i problemi pastorali. La collegialità nei documenti provenienti dall'Africa proconsolare della metà del terzo secolo può essere vista su due livelli: tra i metropoliti (nel caso di Cipriano con i vescovi di Roma e i vescovi di Spagna) e con i vescovi e i chierici della propria provincia. Durante il periodo in cui si sedette nella capitale episcopale di Cartagine, furono convocati in totale 7 sinodi, i cui partecipanti presero posizione sullo scisma di Felicissimus e Novaziano, e al ritorno nella comunità ecclesiale delle persone che erano soggette al decreto di Decio facendo offerte idolatriche, la validità del battesimo da parte di eretici e battesimo bambini. Lo scopo apparente di tali disposizioni era preservare l'unità della Chiesa. San Cipriano, rispettando l'autonomia di ciascun vescovo nella gestione della propria comunità, ha cercato di sviluppare una linea di condotta comune al fine di mantenere l'unità della Chiesa cattolica. Va notato però, che non tutte le risoluzioni dei sinodi di Cartagine hanno contribuito alla dottrina della Chiesa.

Parole chiave: Cipriano di Cartagine; sinodi; collegi episcopali; scismi; eresie

\section{Synody w Afryce prokonsularnej III wieku jako przejaw kolegialności biskupów w świetle Kanonów synodalnych i Listów św. Cypriana z Kartaginy}

(streszczenie)

W połowie III wieku biskupem Kartaginy w Afryce prokonsularnej został wybrany Thascius Caecilius Cyprianus, człowiek zamożny i wykształcony. W czasie prześladowań zarządzonych przez cesarza Decjusza wiara wielu osób została poddana ciężkiej próbie. We wspólnocie chrześcijan powstały podziały na tle dyscyplinarnym i administracyjnym. Św. Cyprian odwołał się do starej tradycji pielęgnowanej nie tylko w Kościele Afryki prokonsularnej, lecz także w innych prowincjach Kościoła powszechnego, którą było zwoływanie synodów w celu wspólnego rozwiązywania powstałych problemów duszpasterskich. W czasach zasiadania przez św. Cypriana na stolicy biskupiej w Kartaginie w sumie zostało zwołanych 7 synodów, których uczestnicy zajęli swoje stanowisko wobec schizm Felicissimusa i Nowacjana oraz w sprawie powrotu do wspólnoty kościelnej osób, które uległy nakazom edyktu Decjusza, dokonując ofiar bałwochwalczych, ważności chrztu udzielanego przez heretyków oraz chrztu dzieci. Niniejsze opracowanie jest próbą ukazania ważnej roli synodów w kształtowaniu kolegialności biskupów w Afryce prokonsularnej w połowie III wieku w kontekście troski o jedność Kościoła. Z drugiej jednak strony ukazuje prawdę, że nie wszystkie uchwały synodów w Kartaginie współtworzyły doktrynę Kościoła.

Słowa kluczowe: Cyprian z Kartaginy; synody; kolegialność biskupów; schizmy; herezje 


\section{Bibliografia}

Thacius Caecilius Cyprianus, Opera omnia, ed. G. Hertel, CSEL 3, t. 1-2, Vindobonae 1868-1871.

Funk F.X., Patres apostolici, t. 2, Tübingen 1901.

Acta Synodalia ann. 50-381, red. A. Baron - H. Pietras, Kraków 2006.

Św. Cyprian, Listy, tł. W. Szołdrski, PSP 1, Warszawa 1969.

Pierwsi świadkowie, red. M. Starowieyski, BOK 10, Kraków 1998.

Bévenot M., Cyprian's Platform in the Rebaptism Controversy, „Heythrop Journal” 19 (1978) s. 123-142.

Bévenot M. „Primus Petro Datur”: St. Cyprian on the Papacy, ,Journal of Theological Studies" 5 (1954) s. 19-35.

Bévenot M., The Sacrament of Penance and St. Cyprian's „De Lapsis”, „Theological Studies" 16 (1955) s. 175-213.

Berardi C.C., La persecuzione di Decio negli scritti di Cipriano, „Auctores nostri” 1 (2004) s. 41-60.

Bobertz Ch.A., The historical context of Cyprian's „,De Unitate”, „The Journal of Theological Studies" 41/1 (1990) s. 107-111.

Bogucki M., Problemy duszpasterskie w listach św. Cypriana, „Studia Theologica Varsaviensia" 9/1 (1971) s. 191-224.

Burns J.P., On Rebaptism: Social Organization in the Third Century Church, „Journal of Early Christian Studies" 1 (1993) s. 367-403.

Clarke W.G., Cyprian's Epistle 64 and the Kissing of Feet in Baptism, „Harvard Theological Review" 66/1 (1973) s. 147-152.

Chłopowiec M., Aspekty historyczne $w$ rozwoju teologii pokuty okresu patrystycznego do św. Cypriana, „Teologia i Moralność” 3 (2008) s. 191-207.

Czyżewski B., Postawa św. Cypriana wobec Apostatów na podstawie jego Listów, „Studia Gnesnensia" 17 (2003) s. 185-202.

Danielou J. - Marrou H.I., Historia Kościoła, t. 1, tł. M. Tarnowska, Warszawa 1986.

Dołganiszewska E., Extra Ecclesiam nulla salus - Cypriana z Kartaginy myśl o Kościele, „Wrocławski Przegląd Teologiczny” 14/1 (2006) s. 141-157.

Drogosz M., Cyprian, biskup Kartaginy wobec swojego kleru (w świetle jego Listów), „Śląskie Studia Historyczno-Teologiczne” 18 (1985) s. 149-167.

Dunn G.D., The Carthaginian Synod of 251: Cyprian's Model of Pastoral Ministry, $\mathrm{w}$ : I concili della cristianità occidentale secoli III-V (XXX incontro di studiosi dell'antichità cristiana, Roma 3-5 maggio 2001), Roma 2002, s. 235-257.

Dunn G.D., Cyprian of Carthage and the Episcopal Synod of late 254, „Revue des Etudes Augustiniennes" 48 (2002) s. 229-247.

Dunn G.D., Heresy and schism according Cyprian of Carthage, „Journal of Theological Studies" 55/2 (2004) s. 551-574. 
Dunn G.D., Cyprian and His Collegae: Patronage and the Episcopal Synod of 252, „Journal of Religious History" 27/1 (2003) s. 1-13.

Dunn G.D., Validity of Baptism and Ordination in the African Response to the "Rebaptism» Crisis: Cyprian of Carthage's Synod of Spring 256, „Theological Studies” 67 (2006) s. 257-274.

Fischer J.A., Das Konzil zu Karthago im Mai 252, „Annuarium Historiae Conciliorum” 13 (1981) s. 1-11.

Fischer J.A., Das Konzil zu Karthago im Frühjahr 253, „Annuarium Historiae Conciliorum" 13 (1981) s. 12-26.

Fischer J.A., Das Konzil zu Karthago im Jahr 255, „Annuarium Historiae Conciliorum” 14 (1982) s. 227-240.

Fischer J.A., Das Konzil zu Karthago im Frühjahr 256, „Annuarium Historiae Conciliorum" 15 (1983) s. 1-14.

Grattarola P., Il problema dei lapsi fra Roma e Cartagine, „Rivista di storia della Chiesa in italia" 38 (1984) s. 1-26.

Grzywaczewski J., The validity of the baptism of heretics according to Cyprian of Carthage, pope Stephan and Firmilian of Caesarea, VoxP 63 (2015) s. 95-112.

Hall H.G., The Versions of Cyprian's De Unitate 4-5: Bevenot's Dating Revisited, ,Journal of Theological Studies" 55/1 (2004) s. 138-146.

Keresztes P., Two Edicts of the Emperor Valerian, VigCh 29/2 (1975) s. 81-95.

Kieling M., Kościół wobec idolatrii na podstawie dokumentów Synodów w latach 50-381, VoxP 55 (2010) s. 276-292.

Knipping J.R., The libelli of the Decian persecution, „Harvard Theological Review” 16 (1923) s. 345-390.

Koch H., Cyprian und der Romische Primat, ,Texte und Untersuchungen” 35 (1910) s. $158-169$.

de Labriolle P.Ch., La crise montaniste, Paris 1913.

Mattei P., L'ecclésiologie de saint Cyprien. Structures et situation historique, „Connaissance des Pères de l'Église” 96 (2004) s. 15-27.

Mattei P., Les frontières de l'Église selon la première tradition africaine (Tertullien, Cyprien, Anonyme De rebaptismate), „Revue des Sciences Religieuses” 81 (2007) s. 27 47.

Misiarczyk L. - Sprusiński P., Warunki powrotu lapsi do wspólnoty kościelnej wedtug Cypriana z Kartaginy, „Studia Płockie” 40 (2012) s. 27-48.

Myszor W., Zagadnienie herezji w listach św. Cypriana, „Studia Theologica Varsaviensia” 9/1 (1971) s. 147-190.

Pastuszko M., Dzieci jako podmiot chrztu, „Prawo Kanoniczne: Kwartalnik prawno-historyczny" 22/1-2 (1979) s. 93-129.

Pietras H., Jeden chrzest na odpuszczenie grzechów - próba zrozumienia świadectw patrystycznych, w: Kościół, świat i zbawienie we wczesnym chrześcijaństwie, red. J. Naumowicz, Warszawa 2004, s. 179-193. 
Powell L.D., Tertullianists and Cataphrygians, VigCh 29/1 (1975) s. 33-54.

Rives J.B., The Decree of Decius and the religion of empire, ,,Journal of Roman Studies”, 89 (1999) s. 135-154.

Roldanus J., No Easy Reconciliation: St. Cyprian on Conditions for Re-integration of the Lapsed, „Journal of Theology for Southern Africa” 92 (1995) s. 23-31.

Shuve K., Cyprian of Carthage's Writings from the Rebaptism Controversy: Two Revisionary Proposals Reconsidered, „Journal of Theological Studies” 61/2 (2010) s. 627-643.

Słomka J., Chrzest i pokuta w Kościele starożytnym. Antologia tekstów I-III w., Kraków 2004.

Słomka J., Nowe proroctwo. Historia i doktryna montanizmu, Katowice 2007.

Sroka S., Nauka św. Cypriana o miłosierdziu chrześcijańskim, Tarnów 1939.

Szram M., Nowacjanie, w: Encyklopedia Katolicka, t. 14, red. E. Giglewicz, Lublin 2010, k. 26.

Taylor J.H., St. Cyprian and the reconciliation of apostates, „Theological Studies” 3/1 (1942) s. 27-46.

Wysocki M., Przebaczenie $w$ pismach św. Cypriana z Kartaginy, „Verbum Vitae” 18 (2010) s. 187-211.

Wysocki M., Model doskonałego chrześcijanina w pismach św. Cypriana z Kartaginy, VoxP 55 (2010) s. 699-720.

Wysocki M., Eschatologiczna nagroda w pismach św. Cypriana, „,Roczniki Historii Kościoła” 56/1 (2009) s. 33-48.

Zmire P., Recherches sur la collégialité épiscopale dans l'Église d'Afrique, „Recherches Augustiniennes" 1 (1971) s. 3-72. 